Dr JOVAN ČAVOŠKI, naučni saradnik

Institut za noviju istoriju Srbije

Beograd, Republika Srbija

jcavoski@yahoo.com

originalan naučni rad

UDK: 327(497.1:5)"195"

primljeno: 25. april 2018.

327(5)"195"

prihvaćeno: 10. oktobar 2018.

https://doi.org/10.29362/ist20veka.2019.1.cav.139-160

\title{
IDEOLOŠKI PRIJATELJ IZ DALEKA: JUGOSLAVIJA I AZIJSKA SOCIJALISTIČKA KONFERENCIJA*
}

APSTRAKT: Rad se bavi već dosta zaboravljenim odnosima Jugoslavije i niza uticajnih azijskih socijalističkih partija, koje su početkom 1950-ih formirale nezavisnu regionalnu političku organizaciju, Azijsku socijalističku konferenciju. Jugoslavija je bila jedini individualni neazijski pridruženi član te organizacije i predstavljala je uzor azijskim socijalistima u njihovoj borbi za nezavisnost od velikih sila i u izgradnji sopstvenog puta u socijalizam. Članak se primarno zasniva na dokumentima iz srpskih, mjanmarskih, indijskih, britanskih, kineskih i američkih arhiva, kao i na publikacijama koje je Azijska socijalistička konferencija objavljivala tokom 1950-ih.

KLJUČNE REČI: Jugoslavija, Azijska socijalistička konferencija, socijalizam, nesvrstanost, „treća“ sila, Burma, Indija

\section{Uvod}

Tokom većeg dela Hladnog rata novooslobođene nacije Azije i Afrike nastojale su da pronađu alternativni model političkog i društveno-ekonomskog razvoja za sopstvena društva, model drugačiji od onoga što su nudila dva dominantna ideološka bloka, a koji bi istovremeno bio tesno povezan sa idejom nesvrstanosti (tada nazivane neutralizam) u međunarodnim odnosima. Ovakva potraga bila je očigledan pokazatelj da su postkolonijalne države želele da se jasno udalje od pređašnjih kolonijalnih gospodara, isto tako držeći distancu i u odnosu na nove predvodnike blokovskih struktura, često zagovarajući ideju „trećeg puta“ ili „treće sile“, kako na spoljnopolitičkom, tako i unutrašnjem političkom planu. Takva ideja, činilo se mnogima od njih, bila je očigledan izraz njihove nezavisnosti, posebnosti i jednakosti u svetskim poslovima. Upravo u ovakva nastojanja neposredno se uklapa i koncept Azijske socijalističke konferencije (ASK) tokom 1950ih, jedan od najslabije shvaćenih političkih fenomena skorašnje azijske istorije.

\footnotetext{
* Rad je deo projekta Srbi i Srbija u jugoslovenskom i međunarodnom kontekstu: unutrašnji razvitak i položaj u evropskoj/svetskoj zajednici (47027), koji finansira Ministarstvo prosvete, nauke i tehnološkog razvoja Republike Srbije.
} 
ASK je bila međunarodna organizacija koja je želela da svet posmatra iz potpuno drugačije ideološke perspektive od onoga što su nudila dva bloka, a činile su je uticajne socijalističke partije u Burmi (Mjanmar), Indiji i Indoneziji, uz aktivno učešće sličnih partija iz Izraela, Japana i sa Cejlona (Šri Lanka), kao i još nekih manjih partija širom tog kontinenta. Isto tako, i Jugoslavija, koja se posle raskola sa Staljinom i sama okrenula stvaranju alternativnog socijalističkog modela, bila je jedan od najbližih saveznika ovih političkih snaga na međunarodnoj pozornici. Iako se mora priznati da, u krajnjem rezultatu, ASK nije bila previše uspešan projekat, ona je ipak odigrala istaknutu ulogu u oblikovanju alternativnog političkog identiteta azijske politike, Jugoslavije i čitavog nesvrstanog sveta u samo predvečerje potonje Azijsko-afričke konferencije u Bandungu. Ova istorijska tema ranije nije bila detaljnije obrađivana, tako da se ozbiljnije studije koje usput prate ovaj fenomen mogu nabrojati na prste jedne ruke, a prisutne su i u ovom članku, dok je ugao socijalističke Jugoslavije bio skoro u potpunosti zanemaren, pre svega zbog nedostatka relevantnih arhivskih izvora. Isto tako, korene istorijskog zaborava ASK u Jugoslaviji možemo tražiti i u činjenici da se ta istorijska epizoda često vezivala za Milovana Đilasa i njegove koncepcije. Prema tome, ovaj članak će zato nastojati da popuni takvu saznajnu prazninu, oslanjajući se, pre svega, na dokumenta iz srpskih, mjanmarskih, indijskih, britanskih, kineskih i američkih arhiva, uz obilato korišćenje brojnih zvaničnih izveštaja, biltena i političkih pamfleta koje je ASK objavljivala u tom periodu.

\section{Jugoslavija i temelji ASK}

Ideološke spone koje su povezivale Jugoslaviju sa različitim azijskim zemljama, naročito sa Burmom, pa i Indijom, zajednička želja da se izgradi specifičan socijalistički model razvoja, kao i nastojanje da se vodi nezavisna spoljna politika na međunarodnoj sceni, bili su blisko u vezi sa nastankom samog pojma azijskog socijalizma i formiranjem ASK. Opasnosti koje su proisticale iz novih blokovskih podela bile su više preteće po sve ove zemlje od bauka starog kolonijalizma, ma koliko se on još uvek činio žilavim. Zato je ASK, u mnogim delovima svog programa, bila i svojevrsna prethodnica Bandunške konferencije, naročito u sferi borbe protiv kolonijalizma i izgradnje političkog identiteta Trećeg sveta, ali je imala idejne veze i sa potonjim Pokretom nesvrstanih zemalja. ${ }^{1}$ Čvrsta veza između koncepta socijalizma i nesvrstanosti činila je ideološku okosnicu delovanja najvećih i najbolje organizovanih azijskih socijalističkih partija u Burmi, Indiji i Indoneziji, mnogo više od samog antikolonijalizma, iako nesvrstanost nikada nije mogla da se javno istakne kao vjeruju ASK usled otpora prozapadnih partija iz Izraela i Japana. ${ }^{2}$ Bez obzira na to, spona između zasebnog puta u socijalizam i vanblokovske spoljne politike predstavljala je snažan podsticaj za povezivanje Jugoslavije sa ovim političkim snagama u Aziji. Isto

\footnotetext{
${ }^{1}$ Kyaw Zaw Win, "The 1953 Asian Socialist Conference in Rangoon: precursor to the Bandung conference", u: Derek McDougall, Antonia Finnane (eds.), Bandung 1955: little histories (Caulfield: Monash University Press, 2010), 53-55.

${ }^{2}$ U Kyaw Nyein, “Common Ties that Bind Us Together”, Socialist Asia, vol. 1, no. 3, (1952), 1.
} 
tako, značaj socijalističkog pokreta u Aziji rano su shvatili i zapadnoevropski socijalisti, tako da su nastojali da prošire svoju organizaciju i na taj prostor. Ulogu mosta ka Aziji često su im omogućavali indijski socijalisti. ${ }^{3}$

Međutim, upravo su Burma i rukovodstvo Socijalističke partije Burme (SPB) predstavljali sigurnu ulaznu kartu za Jugoslaviju u redove azijskih socijalista. Oni su sopstveni put u socijalizam nastojali da pomire sa postulatima budizma, otvoreno se suprotstavljajući komunizmu i insistirajući na punoj nacionalnoj nezavisnosti, kako je to definisao jedan od socijalističkih lidera U Ba Šve. ${ }^{4}$ Američki analitičari su bliskost Jugoslavije sa burmanskim i drugim azijskim socijalistima videli u njihovoj ,opčinjenosti jugoslovenskom sposobnošću da opstanu kao komunistička zemlja, a da se ne potčine ni Moskvi, ni Zapadu“.5 Suštinu ovog odnosa najbolje je definisao drugi lider SPB U Čo Njen: „Jugoslavija i Burma su zemlje koje izgrađuju socijalizam. Njihova spoljna politika se zasniva na očuvanju mira. Zbog toga među njima postoji sličnost interesa i ciljeva“. 6 Štaviše, njegov stav potvrdio je jednom i premijer U Nu rekavši: „I Jugoslavija i Burma dele uverenje da socijalistička država predstavlja najbolji način da se podigne opšte blagostanje, a ta činjenica, plus zajednička vera u miroljubivu koegzistenciju, približili su Jugoslaviju i Burmu“. 7 Sličnosti između dve zemlje bile su više nego očigledne, čime je postojala stabilna osnova za dalji razvoj saradnje na bilateralnom i multilateralnom planu, dok su istovremeno burmanski socijalisti sasvim odbijali da uspostave bilo kakve veze sa zapadnoevropskim kolegama. ${ }^{8}$

Socijalistički pokret u Aziji se sve više identifikovao sa spoljnopolitičkom strategijom neutralizma koju je zagovaralo sve više novooslobođenih zemalja, dok su snažna antikomunistička strujanja u tim zemljama takođe uticala na njih da potraže partnere među alternativnim levim snagama i na drugim kontinentima. U to vreme i Jugosloveni su nastojali da formulišu alternativni socijalistički model, drugačiji od staljinističkog, ali i da izbegnu potpunu izolaciju, tako da su i sami počeli da uspostavljaju veze sa Socijalističkom internacionalom (SI), a tu je glavnu ulogu igrao Đilas, potonji delegat na ASK. ${ }^{9}$ Otvoren jugoslovenski raskid sa Moskvom uticao je na azijske socijaliste da uspostave bližu saradnju sa zvaničnim Beogradom, gledajući u jugoslovenskim komunistima ne samo mogućeg saveznika na svetskoj pozornici, već i očigledan uzor. Dok su Jugosloveni nastojali da iskoriste ove političke snage da otvore vrata različitih azijskih zemalja gde

\footnotetext{
3 Peter Van Kemseke, Towards an Era of Development: The Globalization of Socialism and Christian Democracy 1945-1965 (Lueven: Lueven University Press, 2006), 54-55, 62-63.

${ }^{4} \mathrm{U}$ Ba Swe, The Burmese Revolution (Rangoon, 1952).

${ }^{5}$ Declassified Documents Reference System (DDRS), CK3100016760, Neutralism in the Far East, 7. januar 1955.

${ }^{6}$ Arhiv Jugoslavije (AJ), fond 837, Kabinet Predsednika Republike (KPR), I-2, Elaborat Burma, 149.

${ }^{7}$ Chi-shad Liang, Burma's Foreign Relations: Neutralism in Theory and Practice (New York: Praeger, 1990), 184.

${ }^{8}$ P. Van Kemseke, Towards an Era of Development, 89-90.

${ }^{9}$ Aleksandar Miletić, „Spoljnopolitička delatnost Milovana Đilasa 1944-1953“, u: Jugoslovenska diplomatija 1945-1961: zbornik radova, ur. Slobodan Selinić (Beograd: Institut za noviju istoriju Srbije, 2012), 307-310.
} 
nisu uvek imali intenzivnije kontakte sa tamošnjim vladama, dotle su se azijski socijalisti ugledali na jugoslovensko iskustvo sukoba sa lagerom kako bi se i sami borili protiv lokalnih komunističkih partija koje su bile lojalne Moskvi ili Pekingu. ${ }^{10} \mathrm{Za}$ razliku od burmanskih socijalista koji su imali intenzivnu razmenu sa Jugoslavijom, čak su i njihove indijske i indonežanske kolege, koje nisu bile toliko aktivne na tom planu, povremeno posećivale daleku balkansku zemlju, želeći da uče iz njenog bogatog političkog i ekonomskog iskustva. ${ }^{11}$ Kako su to kasnije primećivali američki analitičari, spoljnopolitička dimenzija otvorene promocije zasebnog jugoslovenskog puta u socijalizam činila je jednu od suštinskih komponenti veza zvaničnog Beograda i afro-azijskih zemalja. ${ }^{12}$

Za razliku od Jugoslovena, međutim, zapadnoevropski socijalisti nikada nisu gledali na svoje azijske kolege kao potpuno jednake, plašeći se, pre svega, njihovog gorljivog nacionalizma i ukorenjene želje da budu potpuno nezavisni, snažnog antiimperijalističkog i antikolonijalnog osećaja, stalnih zahteva za brzim i korenitim preobražajem azijskih društava. Sve je to bilo potpuno drugačije od onoga što je SI zamišljala za azijske zemlje, a to su bili postepen ekonomski razvoj i ograničene promene. ${ }^{13}$ Zato su se mnogi rukovodioci Internacionale otvoreno plašili da bi se azijski socijalisti, u krajnjoj instanci, mogli obratiti za pomoć istočnoevropskim zemljama, uključujući tu i Jugoslaviju. ${ }^{14}$ Međutim, jugoslovenski komunisti se nisu plašili revolucionarnih promena i nacionalnih stremljenja azijskih naroda, gledajući u njima nastavljače globalnog procesa koga su i sami otpočeli deceniju ranije, pozdravljajući tako njihovu punu emancipaciju, kako od bivših kolonijalnih gospodara, tako i od novih ideologa iz Moskve i Pekinga. ${ }^{15}$ Ipak, još uvek je bilo i izvesnih rezervi u redovima azijskih socijalista oko toga da li bi bilo kakva politička organizacija trebalo da se proširi i na druge delove sveta (Bliski istok, Evropa), pošto se ipak radilo o regionima koji su se suočavali sa suštinski različitim problemima od onih koji su postojali u Aziji. ${ }^{16}$

Kao što smo već istakli, burmanski lideri su obilato koristili ideološku saradnju sa Jugoslavijom kao potvrdu ispravnosti sopstvenog političkog kursa, usmerenog na kritiku sovjetskog modela ili isticanje uspeha azijskog socijalizma. ${ }^{17}$ Upravo je poseta velike burmanske civilno-vojne delegacije Jugoslaviji u leto 1952.

${ }^{10}$ Diplomatski arhiv Ministarstva spoljnih poslova Srbije (DA MSP), Politička arhiva (PA), 1952, fascikla (f) 34, dokument 411432, Telegram jugoslovenske ambasade u Indiji, 18. avgust 1952.

${ }^{11}$ Ljubodrag Dimić, Aleksandar Raković, Miladin Milošević, Jugoslavija-Indonezija 1945-1967: istraživanja i dokumenta (Beograd: Arhiv Jugoslavije, 2014), 129-133.

12 National Archives and Records Administration (NARA), Record Group (RG) 59, Central Decimal Files (CDF), 1960-1963, 668.00/4-2661, Yugoslav policy in the underdeveloped countries, 26. april 1961.

${ }^{13}$ Talbot C. Imlay, „International Socialism and Decolonization during the 1950s: Competing Rights and the Postcolonial Order", American Historical Review, vol. 118, no. 4, (2013), 1111-1112.

${ }^{14}$ Kyaw Zaw Win, A History of the Burma Socialist Party 1930-1964, PhD thesis (University of Wollongong, 2008), 229.

15 „Socijalistička konferencija u Rangunu“, Međunarodna politika, god. 3, br. 9 (1952), 6.

${ }^{16}$ DA MSP, PA, 1952, f-35, 46423, Zabeleška o razgovoru sa U Čo Njenom, 11. april 1952.

17 Yoshihiro Nakanishi, Strong Soldiers, Failed Revolution: The State and Military in Burma, 1962-1988 (Singapore, Kyoto: NUS Press, Kyoto University Press, 2013), 66-69. 
pokazala visok stepen zainteresovanosti burmanskih socijalista za proširenje političke, ekonomske i vojne saradnje dve zemlje. U Čo Njen je bio iskreno impresioniran dostignućima jugoslovenskog socijalizma koje je tada video, držeći da je bilo mnogo toga što je Burma mogla da nauči. ${ }^{18}$ Tokom jednog razgovora Đilas je svoje goste upozorio da moraju da izgrade sopstveni socijalistički model kako bi se konačno zaštitili od nasrtaja oba bloka. ${ }^{19}$ Kako se može videti iz jednog kasnijeg izveštaja burmanske ambasade u Beogradu, upravo su uspešni rezultati industrijalizacije Jugoslavije, uprkos izvesnim propustima, bili, po njima, jasna potvrda nezavisnosti i prepoznatljivosti te zemlje na spoljnom planu, a to je itekako fasciniralo burmansko rukovodstvo. ${ }^{20}$ Time su bili postavljeni čvrsti temelji dalje aktivne saradnje Jugoslavije i azijskih socijalista.

\section{Pripreme za ASK}

Ukoliko govorimo o političkom skupu koji možemo nazvati prethodnicom ASK, onda je to bila Prva azijska konferencija (Asian Relations Conference) održana u Nju Delhiju marta-aprila 1947. I ovo je bio skup nezvaničnih predstavnika, kao i ASK, mada još uvek porobljenih azijskih zemalja, na kome se diskutovalo o političkim, ekonomskim, društvenim i međunarodnim problemima koji su morili čitav kontinent, ali se promovisala i buduća saradnja između svih ovih nacija, kako bi se sva ta ograničenja postepeno i prevazišla. ${ }^{21}$ Upravo su se na marginama ovog skupa sastali socijalistički lideri Burme, Indije i Indonezije i tako je ,nastala ideja Azijske socijalističke konferencije“" ${ }^{22}$ Po svedočenju U Čo Njena, jedan od predstavnika britanskih laburista naglasio je tada da su azijske zemlje morale imati sopstvenu političku organizaciju, jer su njihovi problemi bili drugačiji od evropskih. ${ }^{23}$ Već u decembru te godine, na regionalnom skupu koji je u Nju Delhiju organizovala Međunarodna organizacija rada, sastali su se burmanski i indonežanski predstavnici i odlučili su da organizuju sastanak u Rangunu na kome bi se ,odlučilo predstavništvo različitih socijalističkih partija i sastavila agenda Azijske socijalističke konferencije“. Tada je bilo zamišljeno da se uspostavi jedna stalna organizacija koja bi se borila za oslobođenje i zajedničke političke i ekonomske interese azijskih naroda, nastojeći tako da ukloni sve faktore koji su kočili njihov napredak ka punoj nacionalnoj nezavisnosti i socijalizmu. $^{24}$ Iako nije odmah došlo do organizovanja ovakvog skupa, preliminarni program je već ukazivao da su pitanja socijalističke izgradnje, političke i ekonomske nezavisnosti, bili jasan prioritet svih potencijalnih učesnika.

${ }_{18}$ AJ, fond 507, CK SKJ, 507/IX, 17/VI-3, Izveštaj o poseti burmanske delegacije, 26. jul 1952.

${ }^{19}$ AJ, CK SKJ, 507/IX, 17/VI-3, Zabeleška o razgovoru druga Đilasa i predstavnika burmanske ekonomske delegacije U Čo Njena i Maung Đija, 30. jun 1952.

${ }^{20}$ National Archives of Myanmar (NAM), 15/3(6), File 143, A preliminary view of the industrial state of Yugoslavia, avgust 1955.

${ }^{21}$ Asian Relations: Report of the Proceedings and Documentation of the First Asian Relations Conference, New Delhi, March-April 1947 (New Delhi: Asian Relations Organization, 1948), 256-257.

${ }^{22}$ Three Years of Asian Socialist Conference (Bombay: Second Congress ASC, 1956), 4.

${ }^{23}$ AJ, CK SKJ, 507/IX, 144/I-2, Report of the Preliminary Meeting for the Asian Socialist Conference held at Rangoon, 25-29 March 1952, 120.

${ }^{24}$ Saul Rose, Socialism in Southern Asia (New York: Octagon Books, 1975), 4-5. 
Izbijanje Korejskog rata dosta je uticalo da se ponovo istakne ideja sazivanja ASK, ali su sada inicijativu preuzeli burmanski socijalisti. Već u novembru 1950, tokom U Nuove posete Indiji i Pakistanu, lideri SPB su predložili svojim indijskim kolegama da se sazove šira regionalna konferencija socijalističkih partija Burme, Indije, Indonezije i Malaje. ${ }^{25} \mathrm{U}$ isto vreme u Burmi se pojavila ideja da se uspostavi ,grupa neutralnih zemalja u Aziji i van Azije“ koje bi međusobno bile povezane ugovorima o uzajamnoj pomoći na međudržavnom i međupartijskom planu. Burmanci su smatrali da se čisto evropski socijalistički pokret morao preobraziti u ,međunarodni socijalistički parlament“ koji bi podržavao „,politiku aktivne neutralnosti“, a koju su zagovarale te zemlje. ${ }^{26}$ Tako je kasnije jugoslovenskom ambasadoru Josipu Đerđi bilo preneto da se Burma zalagala za sazivanje konferencije azijskih socijalističkih partija, gde bi se definisala nova regionalna politika, te da se ona potom mogla proširiti i na neazijske zemlje, ne bi li se organizovala što šira međunarodna akcija u borbi za mir i protiv globalnih podela. ${ }^{27}$ Sve je ovo jasno ukazivalo da su pitanja azijskog socijalizma bila tesno povezana sa problematikom globalne nesvrstanosti.

Pod uticajem napete međunarodne situacije, a posle posete japanskih socijalista Indiji jula 1951, rešeno je da se Pripremni sastanak ASK održi u Rangunu krajem marta 1952. Ovaj sastanak je tada dosta uznemirio rukovodioce SI činjenicom da se Azija počela samostalno ideološki organizovati, mimo njihovih napora, tako da su pokušali da čitavu stvar kanališu ka stvaranju ekskluzivnog azijskog krila Internacionale, ali bez mnogo uspeha. ${ }^{28}$ Početna ideja je bila da se sama ASK održi već u oktobru te godine, ali je onda, usled organizacionih zahteva, čitav događaj bio odložen za januar naredne godine. Stalni organizacioni komitet činili su predstavnici socijalističkih partija Burme, Indije i Indonezije, dok su učešće uzeli i predstavnici Socijaldemokratske partije Japana, njeno i desno i levo krilo. Sam skup se bavio pitanjima organizacije buduće konferencije, ali su tada preliminarno razmatrana $i$ različita ideološka, ekonomska i spoljnopolitička pitanja, odnos između azijskih socijalista i Internacionale, a dosta pažnje je bilo posvećeno i konceptu „treće sile“ u međunarodnoj politici. ${ }^{29}$ Upravo je redefinisanje specifičnog odnosa između zapadnoevropskih i azijskih socijalista i bilo jedna od glavnih motivacija sazivanja ASK ${ }^{30}$ U uvodnom obraćanju U Čo Njen je istakao da je cilj sastanka rešavanje zajedničkih azijskih problema, naročito ekonomskih, na jednom regionalnom nivo$\mathrm{u}$, zatim izučavanje nasleđa kolonijalizma na tom prostoru, kao i sprečavanje još jednog globalnog konflikta koji je mogao pokrenuti trenutni Hladni rat. ${ }^{31}$

${ }^{25}$ DA MSP, PA, 1950, f-105, 423991, Telegram jugoslovenske ambasade u Indiji, 8. novembar 1950.

${ }^{26}$ DA MSP, PA, 1951, f-68, 42710, Telegram jugoslovenske ambasade u Indiji, 20. februar 1951.

${ }^{27}$ DA MSP, PA, 1951, f-68, 43597, Telegram jugoslovenske ambasade u Indiji, 9. mart 1951.

${ }^{28}$ P. Van Kemseke, Towards an Era of Development, 78-80.

${ }^{29}$ AJ, CK SKJ, 507/IX, 144/I-2, Report of the Preliminary Meeting for the Asian Socialist Conference held at Rangoon, 25-29 March 1952, 4-6.

${ }^{30}$ Report of the First Asian Socialist Conference, Rangoon 1953 (Rangoon: An Asian Socialist Publication, 1953), 33-34.

${ }^{31}$ AJ, CK SKJ, 507/IX, 144/I-2, Report of the Preliminary Meeting for the Asian Socialist Conference held at Rangoon, 25-29 March 1952, 1-3. 
Prema tome, već se na Pripremnom sastanku videlo da će pitanja posebnog azijskog puta u socijalizam i vanblokovske politike pretežno dominirati agendom ovog i budućeg okupljanja. Tako je indijski delegat Madav Gokale naglasio da su azijske zemlje uglavnom patile od dvostruke nejednakosti - unutrašnje, tj. ekonomske nerazvijenosti i spoljašnje, tj. dominacije velikih sila, a oba ta problema bila su podjednako ozbiljna. ${ }^{32}$ Zato svi učesnici nisu želeli da prihvate ni kapitalistički ni komunistički razvojni model, ali ni da se opredele za jedan od dva bloka. Kako su ukazivali neki od učesnika, ideal azijskih socijalista bio je mešoviti model ekonomskog planiranja koji bi podrazumevao nacionalizaciju svih resursa, ali bez staljinističke prisile, dok bi u poljoprivredi dominirao kooperativni način organizovanja. U suštini, to je značilo da su azijske nacije insistirale da se razvijaju uz striktno poštovanje svog dostojanstva, jednakosti i posebnosti, slobodno birajući razvojne mere koje su odgovarale njihovim potrebama i istorijskom iskustvu. ${ }^{33}$ Ovo je i bio osnovni razlog zašto su azijski socijalisti bili izuzetno zainteresovani za jugoslovenski zadružni model u poljoprivredi i stvaranje radničkih saveta u industriji, kao simbola ideološke posebnosti u odnosu na blokove, na čemu su naročito radili burmanski socijalisti posle svoje posete Jugoslaviji. ${ }^{34}$

Kada govorimo o neutralističkim tendencijama na ovom skupu, one su se, pre svega, iskazale tokom debate o ,trećoj sili“ i jasnom otklonu većine učesnika od unutrašnje i spoljne politike velikih sila. Američki posmatrači su tako smatrali da je čitav ovaj skup jasno motivisala ideja da ,slabe nacije, ako žele da prežive, moraju izbeći da budu uvučene u svetsku borbu za moć““35 Kritikujući ratobornu politiku oba bloka, U Čo Njen je naglasio da je zadatak azijskih socijalista da sačuvaju mir ponudivši alternativu ,kapitalističkoj demokratiji i totalitarnom komunizmu u obliku demokratskog socijalizma“, a sve to uprkos nesumnjivom ,preziru i nepoverenju“ koji bi blokovi pokazali prema njima. Po njemu, svetsko javno mnjenje nesumnjivo bi bilo uz azijske socijaliste, pošto ,dominacija ovih blokova predstavlja groblje socijalizma“" ${ }^{36}$ Indijski socijalista Ramanohar Lohija je podržao ovakav stav sopstvenom tvrdnjom da bi samo postojanje trećeg bloka, koji bi popunio jaz između postojećih blokova, nateralo ona druga dva da iskreno proglase politiku miroljubive koegzistencije, pošto je alternativa bio samo rat i sveopšte uništenje. To se jedino moglo postići povećanjem ideološke, ekonomske, pa i vojne snage zemalja tog trećeg bloka, što bi se ostvarilo jačanjem uzajamne saradnje, ali i pridobijanjem javnog mnjenja u Aziji i šire čime bi se taj kontinent postepeno odvojio od utemeljenih interesa velikih sila. ${ }^{37}$ Jugoslovenski posmatrači bili su više nego zadovoljni da su ovakve ideje, ,nezavisne od kapitalizma i kominformizma“, otvoreno dominirale diskusijom na ovom skupu. ${ }^{38}$

\footnotetext{
${ }^{32}$ Isto, 52.

${ }^{33}$ Isto, 54-57, 63-65, 128-132.

${ }^{34}$ AJ, 837, KPR, I-2, Elaborat Burma, 90.

${ }^{35}$ NARA, RG 59, CDF, 1950-1954, 790B.00/10-1352, Political trends in Burma, August 1952, 13. oktobar 1952.

36 AJ, CK SKJ, 507/IX, 144/I-2, Report of the Preliminary Meeting for the Asian Socialist Conference held at Rangoon, 25-29 March 1952, 3, 90.

${ }^{37}$ Isto, 67-68, 77, 79, 91.

38 „Pred konferenciju azijskih socijalista“, Međunarodna politika, god. 4, br. 1 (1953), 5.
} 
Međutim, izvesne razlike između učesnika ponovo su izbile na površinu kada se počelo diskutovati o budućim odnosima između ASK i SI. Japanski delegati, odnosno njihovo desno krilo, već su bili članovi SI, tako da je za njih bilo prirodno da se svi azijski socijalisti pridruže ovoj međunarodnoj organizaciji. S druge strane, indonežanski predstavnici su bili u potpunosti protiv takve ideje, naglašavajući da u budućnosti dve organizacije mogu samo imati formalne odnose. Indijski socijalisti, iako posmatrači u SI, nisu bili za to da ASK postane njen deo, ni grupno, ni pojedinačno, ali su, ipak, bili spremni na kompromis. ${ }^{39}$ Štaviše, burmanski socijalisti su imali snažnih rezervi prema mogućnostima SI da predvodi „treću silu“ i suprotstavi se kapitalističkom bloku. Oni su čak isticali da su zapadnoevropski socijalisti bili blagi prema kolonijalizmu, odnosno da su bili „socijalisti napolju i imperijalisti kod kuće“, tako da su, pre svega, trebali prvo da „dovedu sopstvenu kuću u red“, ako su već želeli da predvode svet. ${ }^{40} \mathrm{Na}$ kraju, pronađeno je kompromisno rešenje da se, usled različitih stavova, pitanje odnosa SI i ASK pokrene tek na budućem skupu i tada pronađe konačan modus uzajamne saradnje. ${ }^{41}$ U suštini, burmanski delegati su dali odlučujući doprinos po pitanju definisanja ideoloških principa i spoljnopolitičkih ciljeva, naročito u odnosu na pojam „treće sile“ i agende buduće konferencije, kao i u slučaju prevazilaženja određenih nesuglasica između učesnika. ${ }^{42} \mathrm{U}$ tome su uživali podršku svojih indijskih kolega koji su jasno ukazivali članovima Internacionale da je cilj azijskih socijalista da daju ,organizovani izraz" pojmu „treće sile“, a ne samo da je prihvate kao ,ideologiju i spoljnu politiku“. 43

Na kraju Pripremnog sastanka doneta je konačna odluka da na budućoj konferenciji u Rangunu učestvuju delegati iz devet zemalja (Burma, Indija, Indonezija, Izrael, Japan, Liban, Malaja, Pakistan i Egipat), kao i posmatrači iz Nepala i afričkih oslobodilačkih pokreta, od kojih će sigurno prisustvovati samo predstavnici Kenije, Tunisa i Ugande. Tada je uvedena i treća, specijalna kategorija pozvanih, tzv. bratske delegacije, koje su činili predstavnici SI, Međunarodnog saveza socijalističke omladine i Komunističke partije Jugoslavije (potonji Savez komunista Jugoslavije). ${ }^{44}$ Ovo je bilo veliko priznanje za jugoslovenske komuniste, pošto su oni bili jedini Evropljani koji su imali čast da samostalno učestvuju na ASK (SI je međunarodna organizacija), a što je bilo još važnije, azijski socijalisti su tako otvoreno priznali jasne razlike koje su postojale između jugoslovenskog i sovjetskog komunizma i jugoslovenskog i zapadnoevropskog socijalizma, držeći tako Jugoslaviju za nešto posebno u svetskoj politici. ${ }^{45}$ Kako su to svedočili indijski socijalisti, kada se povela reč o vezama azijskih socijalista i Evrope,

39 AJ, CK SKJ, 507/IX, 144/I-2, Report of the Preliminary Meeting for the Asian Socialist Conference held at Rangoon, 25-29 March 1952, 80-81, 85-86, 118, 121.

${ }^{40}$ Isto, 92-93.

${ }^{41}$ Isto, $120-123$.

${ }^{42}$ Isto, 130-142.

43 Boris Niclas-Tölle, The Socialist Opposition in Nehruvian India 1947-1964 (Frankfurt am Main: Peter Lang Edition, 2015), 120.

${ }^{44}$ S. Rose, Socialism in Southern Asia, 6-7.

${ }^{45}$ „Pred konferenciju azijskih socijalista“, Međunarodna politika, god. 4, br. 1, (1953), 5. 
Jugoslavija se tu nalazila na prvom mestu i njeno buduće prisustvo je bilo prirodno, iako je bilo izvesnog otpora da njeni delegati budu pozvani, ali je i to bilo vrlo brzo rešeno. ${ }^{46}$ Trebalo bi ovom prilikom naglasiti da je Jugoslavija takođe odlučila da otvori ambasadu u Rangunu baš uoči održavanja prve ASK, što je bio još jedan značajan pomak u daljoj saradnji između dve zemlje, ali i šire. ${ }^{47}$

Odluke VI kongresa SKJ iz novembra 1952. jasno su ukazivale da je Jugoslavija odabrala sopstveni put u socijalizam koji je sada trebalo na pravi način i promovisati u svetu, insistirajući na ideološkoj zasebnosti od oba bloka. ${ }^{48}$ Prema tome, Jugosloveni su uskoro dobro shvatili da bi ovakav pozitivan odnos sa azijskim partnerima mogao i ubuduće da napreduje samo ukoliko se socijalizam ideološki bude tumačio drugačije od klasičnih postulata marksizma-lenjinizma, uvek naglašavajući razlike između sovjetskog hegemonističkog i nedemokratskog birokratizma i jugoslovenskog ,pravog“ i demokratskog samoupravljanja, koje je trebalo da posluži kao uzor za azijske drugove. ${ }^{49}$ Isto tako, Jugoslavija je držala da je koncept „treće sile“ bio mnogo manje formalan od onoga o čemu su razmišljali azijski socijalisti i, pre svega, predstavljao je jedinstvo svih progresivnih snaga u svetu po pitanju problema mira, saradnje, jednakosti, razvoja, odnosno to je bio samo jedan konstruktivan izraz spoljnopolitičke strategije nesvrstanosti. ${ }^{50}$ Zato su neki azijski intelektualci podržali ideju jugoslovenskog predsednika da je ,treća sila“ jedini način da se osnaži saradnja između različitih zemalja u Aziji i tako stvore preduslovi za intenzivniji ekonomski razvoj, ali bez stvaranja trećeg bloka ili povezivanja sa druga dva, što je podjednako bilo opasno, ali uz konkretniju saradnju sa sličnim zemljama u drugim delovima sveta, uključujući tu i Jugoslaviju. ${ }^{51}$

\section{ASK i njeni rezultati}

Prva ASK održana je 6-15. januara 1953. u Gradskoj kući u Rangunu. Ovom skupu prisustvovalo je 177 delegata iz 15 zemalja, od čega ih je najviše bilo iz Indije (77), Japana (30) i Indonezije (26). Burmanskih delegata je bilo manje nego drugih, samo 15, ali su oni, kao domaćini, predsedavali čitavim događajem. Sve druge delegacije nisu imale više od 3 predstavnika. Takav je bio slučaj i sa delegacijama bratskih partija i organizacija, pa su SI predstavljali Klement Atli, Kaj Bjork i Žorž Bido, a SKJ Milovan Đilas, Aleš Bebler i Anton Blažević. ${ }^{52}$ Osim toga, počasni gost na ASK bio je i načelnik jugoslovenskog generalštaba general Ljubo Vučković koji se tada nalazio na čelu vojne misije dobre volje koja

\footnotetext{
${ }^{46}$ DA MSP, PA, 1952, f-51, 45236, Telegram jugoslovenske ambasade u Indiji, 12. april 1952.

${ }^{47}$ NAM, 190 Nga Ma 52, File 103, Appointment of Dobrivoje Vidić as the Yugoslav ambassador to Burma, 25. novembar 1952.

${ }^{48}$ Borba komunista Jugoslavije za socijalističku demokratiju: VI kongres KPJ (SKJ) (Beograd: Kultura, 1952).

49 Alvin Z. Rubinstein, Yugoslavia and the Nonaligned World (Princeton: Princeton University Press, 1970), 40-41.

${ }^{50}$ Josip Broz Tito, Govori i članci, VI (Zagreb: Naprijed, 1959), 246.

${ }^{51} \mathrm{Kol}$, ,Da li je moguća treća sila?“, Međunarodna politika, god. 5, br. 107, (1954), 7-8.

${ }^{52}$ S. Rose, Socialism in Southern Asia, 7-8.
} 
je boravila u Burmi ${ }^{53}$ Svakako, ni ovaj skup nije prošao bez kontroverzi, tako da su postojale brojne nesuglasice između burmanskih domaćina i najbrojnije indijske delegacije oko toga ko će oblikovati tok čitavog događaja. ${ }^{54}$ Isto tako, mnogi su se protivili učešću izraelske Mapaj partije, kako zbog toga što su ih držali više za evropske nego za azijske socijaliste, tako i zato što su delegacije Egipta i Libana odbile da učestvuju na istim sednicama sa izraelskim predstavnicima. ${ }^{55}$

Kao što je to bio slučaj sa Pripremnim sastankom, i na samoj konferenciji u Rangunu dominirale su teme socijalizma i neutralizma, kao neposrednih pandana ideološkim i blokovskim podelama u svetu. U uvodnom govoru predsedavajući U Ba Šve podvukao je pet ključnih tema o kojima je trebalo diskutovati na skupu: pretnja svetskim ratom između blokova koji bi doveo do kraja čovečanstva, konačno oslobođenje kolonija jer je kolonijalizam samo stvarao rat, zahtevi za nacionalnom revolucijom u postkolonijalnim društvima koja bi podrazumevala traganje za optimalnim društveno-političkim sistemom, ekonomski razvoj azijskih naroda putem socijalizma i sve veće uzajamne saradnje, kao i uspostavljanje stalnih tela ASK. Ovakvu agendu konferencije odmah su podržali lideri delegacija Indije, Indonezije i Japana (levo krilo), pre svega prihvatajući burmanski stav da se trebalo sve više oslanjati na sopstvene snage i uzajamnu saradnju i što više smanjiti zavisnost od industrijalizovanih zemalja i bivših metropola. ${ }^{56}$

Kako su to primetili neki zapadni posmatrači, prisustvo jugoslovenskih delegata na ASK, i to baš u trenutku dok je Staljin još uvek bio neumoljiv u odnosu na Tita, mnogima je sugerisalo u kom pravcu će ići debata na skupu. ${ }^{57}$ Iako Aleš Bebler nije bio među prvima koji su se obratili konferenciji, a nije bio ni punopravan član te organizacije već samo predstavnik bratske partije, njegov govor je burmanska štampa objavila odmah posle govora U Ba Švea, što je jasno ukazivalo koliki značaj su domaćini pridavali učešću jugoslovenskih predstavnika ${ }^{58}$ To je bilo jasno i tokom Beblerovog govora kada je podvukao da azijski socijalisti sada prolaze kroz istu onu borbu kroz koju su već prošli jugoslovenski komunisti, tako da je bilo itekako prostora za saradnju i razmenu iskustava. Ovakav stav je naročito podržao čuveni indijski socijalista Džajaprakaš Narajan koji je u svojim nastupima posebno isticao važnost jugoslovenskog iskustva za sudbinu celokupnog azijskog socijalističkog pokreta. ${ }^{59}$ Isto tako, kineskim posmatračima je itekako smetao ton Beblerovog nastupa, jer je on nastojao da diskredituje burmanske komuniste stavljajući ih u isti kontekst spoljne agresije sa kineskim nacionalističkim i karenskim gerilcima. ${ }^{60}$

\footnotetext{
${ }^{53}$ Burma Weekly Bulletin, 14. januar 1953.

${ }^{54}$ Nehru Memorial Museum and Library (NMML), Oral History Interview, Prem Bhasin, 185-186.

${ }^{55}$ S. Rose, Socialism in Southern Asia, 9.

${ }^{56}$ Report of the First Asian Socialist Conference, Rangoon 1953, 8-11.

${ }^{57}$ Frank N. Trager, „Burma's Foreign Policy, 1948-56: Neutralism, Third Force and Rice“, The Journal of Asian Studies, vol. 16, no. 1, (1956), 94.

${ }^{58}$ Burma Weekly Bulletin, 14. 1. 1953.

${ }^{59}$ Aleš Bebler, Putovanja po sunčanim zemljama (Beograd: Kultura, 1954), 136.

${ }^{60}$ Zhonghua renmin gongheguo waijiaobu dang'anguan [Arhiv MIP-a NR Kine] (ZWD), 10500846-02(1), Miandian yu Nansilafu de guanxi, 18. decembar 1958.
} 
U suštini, Bebler je tokom svog nastupa isticao globalni značaj jugoslovensko-sovjetskog sukoba, kako u cilju raskrinkavanja sovjetske propagande, tako i kao podsticaj za nastanak novog ideološkog i političkog kursa u samoj Jugoslaviji. On je tada rekao: „Jugoslavija je dokazala, ne samo da se istinski socijalizam može graditi bez dominacije sovjetske birokratske metropole, već i da se takav socijalizam jedino može graditi kroz otpor neutoljivim hegemonističkim apetitima te metropole. Jugoslovenski primer takođe dokazuje da je moguće u sadašnjem svetu da zemlja, makar i mala, očuva svoju nezavisnost od strane dominacije i razvije sopstvene proizvodne snage samo ako je ta zemlja ujedinjena i odlučna i njen unutrašnji život sledi demokratski put“. Po Bebleru, „temelji miroljubive međunarodne koegzistencije i mira prihvatljivog za sve“ bili su: „,borba protiv agresivnih i hegemonističkih tendencija, za saradnju naroda i država zasnovanoj na jednakosti, za pravo naroda na samoopredeljenje i za pomoć razvijenih zemalja nerazvijenim" ${ }^{61}$ Ove reči je pozitivno primila većina učesnika jer su, u mnogo čemu, bile u skladu sa konceptom „treće sile“ koji je itekako strujao redovima ASK.

Posle svih uvodnih govora, celokupan rad konferencije bio je podeljen na tri komiteta koja su se bavila određenom problematikom: ideologija i spoljna politika, agrarni i ekonomski razvoj i antikolonijalna borba. ${ }^{62}$ Problemi agrarnog i ekonomskog razvoja izazivali su najmanje kontroverzi i bili su obeleženi vrlo profesionalnom debatom, ali su ih predstavnici SI otvoreno zaobilazili jer nisu predstavljali nikakav izazov za njih. Tako je Bebler, i ovog puta, dao veliki doprinos da se sastavi konačna rezolucija po tom pitanju. ${ }^{63} \mathrm{U}$ suštini, drugi komitet je usmerio svoje predloge na ukidanje kmetstva, nacionalizaciju i preraspodelu zemlje i resursa unutar zemlje i među siromašnima, ubrzanje industrijskog razvoja, smanjenje siromaštva i snaženje nižih klasa putem demokratske kontrole i decentralizacije. ${ }^{64}$ Indijski socijalisti su smatrali da je ovo jedino bilo moguće putem intenzivnog razvoja poljoprivrede, uz izbegavanje negativnih efekata ubrzane industrijalizacije, kao i radikalnim poboljšanjem položaja seljaštva uopšte. ${ }^{65}$ Jugoslovenska i izraelska dostignuća u organizaciji poljoprivrede bila su jedna od glavnih tema na ovom komitetu, pravi uzor za sve azijske socijaliste. ${ }^{66}$ Pod uticajem ovih odluka, na potonjem sastanku Biroa ASK u Tokiju novembra 1954. konačno je doneta rezolucija koja je tražila uspostavljanje radnih grupa koje bi se bavile problemima SUNFED-a, specijalizovanog tela UN za ekonomski razvoj, platne unije u Aziji, pula novinskih agencija ASK, kontrole cena sirovina, zemljišne reforme i planiranja porodice. ${ }^{67}$ Mnoge od ovih ideja kasnije će se pojaviti i u delatnosti Pokreta nesvrstanih zemalja, tako da su njihovi koreni bili mnogo dublji nego što se ranije mislilo.

\footnotetext{
${ }^{61}$ Report of the First Asian Socialist Conference, Rangoon 1953, 21-22.

${ }^{62}$ Isto, 29-30.

${ }^{63}$ A. Bebler, Putovanja po sunčanim zemljama, 126.

${ }^{64}$ Three Years of Asian Socialist Conference, 17-23.

${ }^{65}$ National Archives of India (NAI), Ministry of External Affairs (MEA), 3(12)-R\&I/54, Annual political report from the Indian embassy in Burma for 1953.

${ }^{66}$ Report of the First Asian Socialist Conference, Rangoon 1953, 38.

${ }^{67}$ Myanmar Historical Commission (MHC), Historical Research Center (HRC), Preliminary Report of the $4^{\text {th }}$ Bureau Meeting of the ASC held at Tokyo, 19-21 November 1954.
} 
Isto tako, ASK je posvetila dosta pažnje pitanju borbe protiv kolonijalizma u Aziji, ali i u Africi, kao i problemu poštovanja elementarnih ljudskih prava naroda ta dva kontinenta. U suštini, ASK je bila prva međunarodna organizacija koja je pokušala da se nametne kao najviši politički autoritet koji bi koordinisao međunarodnu antikolonijalnu borbu između oslobođenih i porobljenih nacija u Aziji i Africi. ${ }^{68}$ Međutim, azijski socijalisti svoju ulogu u ovakvom ambicioznom poduhvatu nisu videli kao čin snaženja sopstvene pozicije u kolonijama ili naspram oba bloka, već kao deo šire borbe za slobodu koja je bila nedeljiva i bila je preko potreban preduslov za uspešnu socijalističku izgradnju tih nacija i u budućnosti. ${ }^{69}$ Prema tome, pitanje antikolonijalne borbe za njih nije bilo samo po sebi cilj, već je bilo tesno povezano sa konceptom budućeg unutrašnjeg i spoljnog razvoja azijskih i afričkih zemalja. ASK je tada zvanično pružila odlučnu podršku borbi za potpuno oslobođenje Alžira, Južne Afrike, Kenije, Malaje, Maroka i Ugande. ${ }^{70}$

Što se tiče borbe protiv kolonijalizma, već tokom svog boravka u Rangunu Đilas je predložio britanskim diplomatama i burmanskim zvaničnicima da se pruži aktivna podrška azijskim antikolonijalnim pokretima, kakav je npr. bio Ho Ši Minov Vijetmin, jer, iako su ih predvodili komunisti, oni nisu bili ni sovjetske ni kineske marionete, već autentični revolucionari, vrlo slično Jugoslovenima. ${ }^{71}$ Kao posledica ovakvih nastojanja, već u maju 1954. na sastanku u Kalou u Indoneziji, bio je uspostavljen Antikolonijalni biro ASK, koji je trebalo da koordiniše pomoć antikolonijalnim i narodnooslobodilačkim pokretima u Aziji i Africi. Njegov predsedavajući postao je U Čo Njen, dok je sekretar bio Džim Markam, borac za slobodu iz Zlatne Obale (Gane). Tada je burmanski socijalista pokrenuo pitanje novog, ,sovjetskog tipa kolonijalizma“ koji je, po njemu, postajao još opasniji od starog, ali su to delegati odbili da razmatraju, držeći da bi takva vrsta jednostrane osude ukinula neutralističku orijentaciju čitave organizacije. Svaki imperijalizam se morao podjednako osuditi, smatrala je većina. ${ }^{72} \mathrm{Na}$ ovom sastanku bilo je još odlučeno da ASK posreduje u rešavanju krize u Indokini, dok su Burma i Jugoslavija dobile zadatak da pruže preko potrebnu materijalnu pomoć afričkim studentima u njihovoj borbi za slobodu, čime su obe zemlje neposredno pomagale stvaranje postkolonijalnih elita. ${ }^{73}$ Tada se počelo ozbiljno razmišljati i o organizovanju panafričke socijalističke konferencije $u$ saradnji sa čuvenim afričkim revolucionarom Kvame Nkrumahom, kako bi se i taj kontinent konačno odvojio od blokova i krenuo samostalnim putem razvoja. ${ }^{74}$

\footnotetext{
${ }^{68}$ Burma Weekly Bulletin, 4. 2. 1953.

${ }^{69}$ Report of the First Asian Socialist Conference, Rangoon 1953, 53.

${ }^{70}$ Three Years of Asian Socialist Conference, 31-34.

${ }^{71}$ British Documents on Foreign Affairs (BDFA), Part 5, Series E, Asia, 1953, Vol. 5 (University Publications of America, 2007), 86.

${ }^{72}$ MHC, HRC, Report of the Anticolonial Bureau of the ASC held at Kalaw, 23-24 May 1954.

${ }^{73}$ NAI, MEA, B/54/1333/4-5, Report from the Indian embassy in Burma for the month of May 1954.

74 NARA, CIA Records Search Tool (CREST), CIA-RDP80-00810A002601000010-1, ASC activities for 1954, 23. oktobar 1953.
} 
Debata u prvom komitetu o ideološkim i političkim pitanjima bila je najintenzivnija, a problemi prirode socijalizma, „treće sile“ i saradnje sa SI dominirali su radom ovog tela. Većina učesnika prihvatila je Narajanovu definiciju azijskog socijalizma koji se zasnivao na jednakosti, slobodi od izrabljivanja, ličnoj slobodi, zadružnom životu i neposrednom učešću u politici i ekonomiji, uz razvoj malih proizvodnih jedinica. ${ }^{75}$ Mnogima je tada bilo jasno da je ovakav socijalistički model nastao pod znatnim uticajem jugoslovenskog iskustva, tako da je Đilas odmah ukazao učesnicima da se ,razvoj socijalizma može odvijati duž različitih puteva“, što je bilo uslovljeno ,uzajamnom saradnjom između svih socijalista na svetu“, odnosno da je svako tražio sopstveni put razvoja, ali uz oslonac na slične snage širom sveta. ${ }^{76}$ Ipak, Narajan je držao da nisu postojali različiti putevi u socijalizam, već samo jedan put, ,put demokratskog socijalizma“ i on nije imao alternativu, što se donekle moglo tumačiti i kao prećutna kritika ranijeg staljinističkog kursa u Jugoslaviji. U Čo Njen je podržao ovakav stav svog indijskog kolege, naglasivši da je cilj debate bio da nauči azijske socijaliste da ne upadnu u zamku kapitalizma ili totalitarnog komunizma, već da razvijaju sopstveni demokratski socijalizam, kako ga je on slikovito nazvao „treći način života“، ${ }^{77}$

Bez obzira na sve, usvojena rezolucija o ,Principima i ciljevima socijalizma“ bila je tesno povezana sa debatom o ,trećoj sili““ i punoj nacionalnoj nezavisnosti. Uprkos Narajanovim primedbama, konačan tekst ovog dokumenta uzeo je u obzir Đilasove primedbe o međunarodnoj različitosti socijalizma i takav stav postao

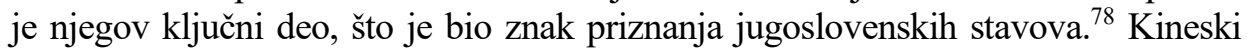
posmatrači su čak smatrali da se Jugoslavija neposredno nalazila iza antikomunističkog tona čitave ove rezolucije, naročito po pitanju otvorene kritike sovjetske i kineske politike. ${ }^{79}$ Isto tako, uticaj negativnog jugoslovenskog iskustva sa lagerom mogao se videti i u delu rezolucije koji je podneo Narajan, a koji se ticao odnosa između socijalističkih zemalja. Po njemu, takvi odnosi morali su se zasnivati na „uzajamnoj pomoći i jednakosti“ gde bi razvijenija socijalistička država trebalo da pomaže onu manje razvijenu, a ne da nastoji da njom dominira. ${ }^{80}$ Osvrt na sovjetsko-jugoslovenski sukob bio je više nego jasan. Kako su to primećivali američki analitičari, konferencija je bila mnogo više kritična prema SSSR-u nego prema SAD, što im je odgovaralo, dok ni američki saveznici, Britanija i Francuska, nisu baš najbolje prošli, ali Amerikance to nije nimalo uznemirilo. ${ }^{81}$

$\mathrm{S}$ druge strane, debata o prirodi azijskog socijalizma bila je takođe tesno povezana sa donošenjem druge rezolucije o „Zajedničkim problemima Azije“, gde su bili jasno definisani svi problemi koji su morili taj džinovski kontinent

\footnotetext{
${ }^{75}$ Report of the First Asian Socialist Conference, Rangoon 1953, 41-42.

${ }^{76}$ Isto, 44.

${ }^{77}$ Isto, 46-47.

${ }^{78}$ Three Years of Asian Socialist Conference, 12-16.

${ }^{79}$ ZWD, 105-00846-02(1), Miandian yu Nansilafu de guanxi, 18. decembar 1958.

${ }^{80}$ G. S. Bhargava, „Positive Aspects of Asian Socialism“, Pacific Affairs, vol. 26, no. 3, (1953), 243-244.

${ }^{81}$ NARA, RG 59, CDF, 1950-1954, 790B.00/3-1653, Political report, January-February 1953, 16. mart 1953.
} 
(feudalizam, religiozni fanatizam, diskriminacija žena, separatizam, strano mešanje, ideološka konfuzija). Azijski socijalisti su otvoreno osudili lokalne političare koji su izbegavali da se ozbiljnije uhvate u koštac sa unutrašnjim problemima i nisu želeli da se suprotstave blokovskoj politici u regionu, iako je ona samo dalje potpomagala separatističke i reakcionarne snage na tom prostoru. Zato su oni nudili konstruktivno rešenje, nasuprot „sterilnoj“ politici zapadnoevropskih socijalista, u upotrebi svih političkih metoda, čak i onih koje ,nisu bili ustavne“, kako bi se mobilisale široke narodne mase za „miroljubivu masovnu akciju“. „Azijski socijalizam morao je biti dinamičan, a ne postepen“, odnosno potpuno različit od onoga što je zagovarala SI. ${ }^{82}$ Ovakav tekst rezolucije bio je direktan odgovor na ranije kritike zapadnoevropskih socijalista, dajući tako azijskom socijalizmu jedan revolucionarni pečat koji ga je činio mnogo bližim drugim autentičnim revolucionarnim pokretima u svetu. ${ }^{83}$

Pomenuta rezolucija se, isto tako, direktno nadovezala na britanske strahove da bi azijski socijalisti konačno mogli da stvore regionalnu organizaciju koja bi u potpunosti bila odvojena od Internacionale, što bi vremenom moglo potkopati pozicije zvaničnog Londona na tom prostoru. Zato je u Rangun i bio poslat bivši premijer Atli, kao najznačajniji član rukovodstva te organizacije. ${ }^{84}$ On je odmah pozvao na uspostavljanje bliskih političkih i organizacionih veza između ASK i SI, u čemu su ga otvoreno podržali delegati iz Izraela, Japana (desno krilo) i Malaje, koji su želeli punopravno članstvo ove organizacije u Internacionali, ali su predstavnici Burme, Indije, Japana (levo krilo), Pakistana i Egipta nedvosmisleno odbili takav predlog, tako da je na kraju tek bilo odlučeno da dve međunarodne organizacije ipak imaju formalnu vezu, ali ASK nikada nije postala integralni deo SI. ${ }^{85}$ Ipak, na sastanku Biroa ASK u Tokiju potom je bila doneta dopunjena odluka da se uzajamna saradnja ipak promoviše kroz zajedničke publikacije i organizovanje političkih konferencija, ali opet bez ikakvog formalnog pridruživanja ASK tom čisto evropskom telu. ${ }^{86}$

Kada se, međutim, povela debata o tekstu rezolucije „Azija i svetski mir“, ponovo je došlo do žestokih razmimoilaženja oko koncepta „treće sile“ i neutralizma, kao i tokom Pripremnog sastanka. Burmanski, indijski i indonežanski delegati suočili su se sa žestokim otporom izraelskih i japanskih (desno krilo) predstavnika, a oni su uživali i prećutnu podršku gostiju iz redova $\mathrm{SI}^{87} \mathrm{U}$ početku je bio iznet japanski (levo krilo) predlog da se ASK otvoreno distancira od oba bloka, kao i svih vojnih saveza u Aziji, te da jasno i nedvosmisleno zauzme neutralan stav u azijskoj politici, što je bilo široko prihvaćeno od mnogih delegata (Egipat, Indonezija, Malaja, Pakistan) koji su tvrdili da je ,treća sila“ bila način na koji je ,demokratski socijalizam" davao svoj konkretan doprinos stabilizaciji svetskih prilika. Bez obzira na

\footnotetext{
${ }^{82}$ Three Years of Asian Socialist Conference, 29-30.

${ }^{83}$ Report of the First Asian Socialist Conference, Rangoon 1953, 61.

${ }^{84}$ BDFA, Part 5, Series E, Asia, 1953, vol. 5, 74-75.

${ }^{85}$ Report of the First Asian Socialist Conference, Rangoon 1953, 32-35.

${ }^{86}$ MHC, HRC, Preliminary Report of the $4^{\text {th }}$ Bureau Meeting of the ASC held at Tokyo, 19-21 November 1954.

${ }^{87}$ NMML, Prem Bhasin Collection, Subject File 3, 167-170.
} 
sve, izraelski i japanski (desno krilo) predstavnici su tvrdili da je to bilo nerealno i nepraktično, pa su blokirali prihvatanje takvih formulacija. ${ }^{88}$ Zato su neki indijski delegati otvoreno optužili izraelske $i$ japanske kolege da oni nikada nisu ni bili stvarno kolonizovani, a da je Japan čak bio i kolonizator, tako da nisu ni mogli da razumeju postkolonijalna društva, niti da se sa njima iskreno identifikuju. ${ }^{89}$

Burmanski i indijski predstavnici su zastupali stav da je „treća sila“ bila samo reakcija na dominantne međunarodne faktore koji su uticali na nastanak fenomena azijskog socijalizma i neutralizma: rivalstvo dva bloka, ekonomska nejednakost, opstanak kolonijalizma, agresivnost oba bloka na tom prostoru. Zato je U Čo Njen otvoreno insistirao da se azijski socijalisti drže podalje od blokova i samostalno rade na očuvanju mira na kontinentu, ali i šire. ${ }^{90}$ Ipak, pod uticajem Izraelaca koji su imali bliske odnose sa Burmom, domaćini su prihvatili da se ideja ,treće sile“ zvanično ne uključi u tekst ove rezolucije, iako to nikako nije značilo da koncept neutralizma nije bio važan za pojedinačne članove ili tu organizaciju u celini. ${ }^{91}$ Uprkos svemu, u konačnom tekstu rezolucije bilo je više nego očigledno da su protivljenje politici interesnih sfera i agresivnoj politici oba bloka i očuvanje principa UN bili u samom vrhu prioriteta ASK. ${ }^{92}$ Upravo su bliske konsultacije jugoslovenskih, burmanskih i indijskih predstavnika doprinele da se konačno uobliči tekst ove rezolucije, usvoje ideje o ,trećoj sili“", kao i da se odustane od preterane integracije sa SI. ${ }^{93}$ Kako je to preneo burmanski otpravnik poslova u Beogradu, mnoge od formulacija koje su preovladavale u rezolucijama ASK bile su identične sa jugoslovenskim gledištem, odnosno da su ih konačno oblikovali jugoslovenski delegati. ${ }^{94}$

Jedna od ključnih odluka konferencije u Rangunu bila je uspostavljanje stalnih tela ASK: Konferencija, Biro i Sekretarijat. Tako je Konferencija postala najviše telo ASK, nešto slično parlamentu, čiji su članovi bile sve socijalističke partije Azije (jedna partija po zemlji, osim Japana), a ona se sastajala svake dve godine i predsedavajući je bio U Ba Šve. Biro je postao izvršno telo ASK, sastajao se svaki šest meseci i bavio se političkim pitanjima i problemima članstva. Što se tiče Sekretarijata, njegova dužnost je bila da priprema sastanke ove organizacije i bavi se rastućom izdavačkom delatnošću. ${ }^{95}$ Uprkos svim tim odlukama, ova tela se i nisu baš redovno sastajala. Međutim, tada je takođe bilo odlučeno da i SKJ postane pridruženi član Biroa ASK koji je svoj prvi sastanak održao već avgusta 1953. u Hajderabadu u Indiji. Tada je SKJ predstavljao ambasador u Burmi Dobrivoje Vidić, dok je SI zastupao predsedavajući Morgan Filips. Inače,

\footnotetext{
${ }^{88}$ Report of the First Asian Socialist Conference, Rangoon 1953, 47-48.

${ }^{89}$ Boris Niclas-Tölle, The Socialist Opposition in Nehruvian India, 154-155.

${ }^{90}$ Report of the First Asian Socialist Conference, Rangoon 1953, 49.

${ }^{91}$ S. Rose, Socialism in Southern Asia, 9-10.

${ }^{92}$ Three Years of Asian Socialist Conference, 25-27.

${ }^{93}$ AJ, 836, Kancelarija Maršala Jugoslavije (KMJ), I-3-b/157, Đilasovo i Beblerovo pismo Kardelju, 11. januar 1953.

94 AJ, 837, KPR, I-5-b, Burma, Zabeleška o razgovoru druga Koče Popovića i burmanskog otpravnika poslova U Tin Maung Đija, 19. januar 1953.

${ }^{95}$ Burma Weekly Bulletin, 21. 1. 1953.
} 
azijski socijalisti i dalje su bili nezadovoljni kako je Internacionala tretirala kolonijalno pitanje na svojim kongresima, zamerajući joj na blagim i dvosmislenim reakcijama, što nikako nije doprinosilo atmosferi uzajamnog približavanja. ${ }^{96}$

Tokom sastanka u Hajderabadu bila je doneta odluka da se formalno organizuje rad Sekretarijata, uspostavi zvaničan kontakt sa SI, otpočne sa širokom izdavačkom delatnošću, organizuje sastanak ekonomskih stručnjaka, kao i da se uspostavi Antikolonijalni biro. Isto tako, delegati su se bavili i problemom ilegalnog prisustva kineskih nacionalističkih trupa u Burmi, razmatrali su se problemi mira u Koreji i Indokini, kao i pitanje članstva NR Kine u UN, a objavljena je i izjava podrške socijalistima na Bliskom istoku. Iako je bilo izvesnih primedbi na prisustvo predstavnika SKJ, pošto se radilo o vladajućoj komunističkoj partiji, pa su neki pozivali da se isključe jugoslovenski učesnici, dok su drugi tražili da se zauzvrat uspostave organizacione veze sa SSRNJ, ipak burmanski i indijski predstavnici brzo su prekinuli ovakvu debatu konstatacijom da je SKJ potvrdio opravdanost svog učešća u organima ASK još onda kada je ušao u otvoren sukob sa Kominformom. ${ }^{97}$ Ovo je zaista bila argumentacija kojoj niko nije imao šta da suprotstavi. Ipak, bilo je tada i onih u SKJ koji su smatrali da su predložena dokumenta u Hajderabadu bila bleda i previše neutralna, tako da nisu mogla da „deluju mobilizatorski kod svetskog javnog mišljenja“, dok se, isto tako, nije dovoljno insistiralo na principima jednakosti i nemešanja. ${ }^{98}$

Većini spoljnih posmatrača svakako nije mogao da promakne značaj jugoslovenskog učešća na konferenciji u Rangunu. Kao što to možemo videti iz jednog britanskog izveštaja, na Jugoslovene se podjednako gledalo sa zebnjom i nipodaštavanjem. Često se tvrdilo da su oni samo znali da kritikuju staljinizam, ali nisu ,svojom ideologijom“ mogli da pomognu ,stvar demokratskog socijalizma“", dok su britanske diplomate znale i da sarkastično zaključe da bi članstvo u Sekretarijatu ASK moglo da natera jugoslovenske komuniste da postanu ,više demokratski“.99 Jugoslovensko učešće na ovom skupu toliko je iritiralo Britance da je njihov ambasador jednom zajedljivo upitao Đilasa i Beblera: „Šta vi izvozite u Burmu, kakvi su vaši interesi ovde?" Kada su oni odgovorili da su tu zbog sličnosti u idejama, zbog idejne saradnje, ambasador je ironično zaključio: „Vi znači, izvozite ideje“. ${ }^{100}$ Ono što je, isto tako, imalo uticaj na negativan britanski stav prema jugoslovenskom učešću bila je činjenica da su predstavnici SKJ presudno uticali na odluku ASK da ne postane regionalna organizacija SI, već samo ravnopravan međunarodni partner. ${ }^{101}$ Britanci su, međutim, uskoro otkrili da su Jugosloveni izvozili i nešto drugo u Burmu, a to je bilo oružje, što je potom dovelo do okončanja ranijih odbrambenih sporazuma između Londona i Ranguna. ${ }^{102}$

\footnotetext{
${ }^{96}$ P. Van Kemseke, Towards an Era of Development, 96-97.

${ }^{97}$ NAM, 15/3 (3), File 62, ASC Bureau meeting, Hayderabad, August 10-13 1953.

${ }^{98}$ AJ, CK SKJ, 507/IX, 144/I-6, Pismo Vladimira Dedijera Dobrivoju Vidiću, 16. jul 1953.

${ }^{99}$ BDFA, Part 5, Series E, Asia, 1953, Vol. 5, 76.

${ }^{100}$ Milovan Đilas, Vlast i pobuna (Beograd: Književne novine, 1991), 255.

${ }^{101}$ AJ, 836, KMJ, I-3-b/157, Beblerovo pismo Kardelju, 9. januar 1953.

102 Jovan Čavoški, ,Arming Nonalignment: Yugoslavia's Relations with Burma and the Cold War in Asia, 1950-1955”, CWIHP Working Paper, no. 61, (Washington, DC: Woodrow Wilson Center, 2010).
} 
U svakom slučaju, svima je bilo jasno da su jugoslovenski delegati uživali ogromnu popularnost među ostalim učesnicima, naročito među Burmancima i Indijcima, dok je uticaj jugoslovenskih pogleda na većinu zvaničnih dokumenata konferencije bio više nego primetan. ${ }^{103}$ Mnogi od učesnika nastojali su da saznaju od Beblera i Đilasa nešto više o Jugoslaviji, njenom istorijskom iskustvu, dok su se njih dvojica aktivno družili sa svima, uključujući i posete običnim ljudima u burmanskoj prestonici. ${ }^{104}$ Kada se njihov nastup uporedi sa Atlijevim, onda je svima bilo jasno koliko su stavovi zapadnoevropskih socijalista bili daleko od azijske stvarnosti, dok su Jugosloveni često uspevali da ispravno napipaju puls jednog dalekog sveta. ${ }^{105} \mathrm{U}$ stvari, već na ovoj konferenciji jugoslovenski predstavnici su videli jasnu globalnu tendenciju suprotstavljanja blokovskim podelama i postepenog nastanka ,treće sile“ u međunarodnim odnosima, ma koliko god ona još uvek bila u začetku. Oni su, isto tako, videli da su i problemi ekonomskog razvoja nerazvijenih zemalja i borba protiv kolonijalizma postali ključne teme ovog skupa, nešto čemu je i Jugoslavija sve više posvećivala pažnju. Zato su Đilas i Bebler, osim ove ideološke dimenzije saradnje sa azijskim socijalistima, videli i ogromnu ekonomsku korist koju bi Jugoslavija mogla imati i od trgovine sa Burmom i svim ovim zemljama, pre svega putem davanja jevtinih kredita $i$ intenzivnijom trgovinskom razmenom. ${ }^{106}$

Kasnije je Đilas pisao da je ASK jasno pokazala da politika u Aziji više nije bila ,privilegija kolonizatora, domaćih feudalaca ili buržoazije“, već novih socijalističkih snaga koje nisu bile ni dogmatske ni pristrasne u svojim stavovima, nego najbolji primer uzajamne tolerancije, jednakosti i otvorenosti. On je naročito isticao činjenicu da je najvažnija karakteristika azijskog socijalizma bilo to da je on ,stvaralački čin samih azijskih naroda“, a da nije bio uvezen iz drugih delova sveta, što je jasno ukazivalo na njegovu autentičnost koju je imala i Jugoslavija. ${ }^{107}$ U drugom članku Đilas je ukazao da je jedan od najvećih doprinosa ove konferencije bilo ,ponovno otkriće seljaka u socijalističkom pokretu“, odnosno da se socijalizam polako okretao nekim idejama šireg političkog učešća i vraćao se nekim alternativnim konceptima. ${ }^{108}$ Osim toga, ASK je, po njemu, takođe potvrdila da je postojao istinski socijalistički pluralizam u svetu, da su se ,životne tendencije ispoljavale socijalističkije od socijalističkih učenja", odnosno da je socijalizam bio naprosto urođen u Aziji i da su ga ljudi sami usvajali i prilagođavali sopstvenim potrebama, bez straha od spoljnih autoriteta. ${ }^{109}$

S druge strane, Bebler je, slično Đilasu, smatrao da je konferencija u Rangunu svoj najveći doprinos dala na planu rešavanja agrarnog i kolonijalnog pitanja, odnosno da azijski socijalisti nisu imali bilo kakvih predrasuda prema seljacima i pokazivali su snažan revolucionarni duh u odnosu na probleme kolonijalizma i

\footnotetext{
${ }^{103}$ AJ, CK SKJ, 507/IX, S/a-19, SSRNJ i socijalistička konferencija u Rangunu, 20. januar 1954.

${ }^{104}$ A. Bebler, Putovanja po sunčanim zemljama, 123-125.

${ }^{105}$ M. Đilas, Vlast i pobuna, 253.

106 AJ, 836, KMJ, I-3-b/157, Đilasovo i Beblerovo pismo Kardelju, 11. januar 1953.

107 AJ, fond 142, SSRNJ, Komisija za međunarodne veze, f-38, Azijska socijalistička konferencija, 1953.

${ }^{108}$ NAM, 15/3 (3), File 62, ASC Bureau meeting, Hayderabad, August 10-13 1953.

${ }^{109}$ M. Đilas, Vlast i pobuna, 253.
} 
sovjetske dominacije. On je čak držao da je Jugoslavija vremenom trebalo da postane tačka susreta između evropskog i azijskog socijalizma, uprkos određenim rezervama koje su pokazale azijske kolege prema takvim idejama. ${ }^{110}$ Nešto slično je zagovarao i Vladimir Dedijer koji je smatrao da je SSRNJ trebalo da preuzme vodeću ulogu od SKJ u kontaktima sa azijskim i afričkim političkim organizacijama kako bi se izbegle organizacione kontroverze i očuvao visok nivo uzajamne zainteresovanosti za saradnju, van čvrstih ideoloških okvira. U takvim pogledima se jasno ogledao uticaj konferencije u Rangunu. ${ }^{11}$ Tako je već krajem februara 1953. jedan od vođa SPB Bo Kin Maung Gale posetio Beograd i uzeo je učešće na kongresu SSRNJ. Osnovni cilj ove posete bio je da se dalje unaprede veze burmanskih i azijskih socijalista sa Jugoslavijom, ali i da se jugoslovenske kolege podstaknu da šire pozitivnu propagandu o ASK među zapadnoevropskim socijalistima. ${ }^{112}$

Kao što smo mogli videti, jugoslovenski predstavnici su bili u pravu kada su zaključili da je koncept „,treće sile“, pre svega u moralnom smislu značenja tog pojma, stajao iza čitave konstrukcije ASK, čak više i od samog pojma socijalizma, uprkos formalnim karakteristikama. I moralno i politički, ali ne i vojno, ovaj koncept je predstavljao način da se male zemlje brane i postignu unutrašnji i spoljni napredak uprkos nedostatku „tvrde moći“. Tim putem ove zemlje su mogle da, u svakom trenutku, mobilišu svetsko javno mnjenje iza najslabijih članova međunarodnog poretka, apelujući tako na delikatnu ravnotežu snaga u svetu. ${ }^{113}$ Kako je to naglasio Narajan u svom završnom govoru, borba za mir, a ne za rat, stajala je iza ideje ASK, pošto nijedna od ovih zemalja ne bi mogla da opstane u slučaju novog svetskog rata. ,Zato se moramo držati podalje od rivalstava i manevara dva bloka $\mathrm{i}$ da, živeći u miru sa oba, sarađujemo među sobom kako bi stvorili novu snagu koja bi postala stvarna garancija mira“, rekao je tada on. ${ }^{114}$ Prema tome, sva ova dešavanja neposredno su ukazivala da je postojala snažna ideološka, politička i principijelna veza između jugoslovenskih komunista i azijskih socijalista koja je nastavila da se razvija, kako kroz institucije ASK, tako i kroz zvanične odnose sa vladama i drugim političkim snagama na tom prostoru.

\section{Zaključak}

Kada se konferencija u Rangunu završila činilo se svima da se radilo o velikom uspehu za čitav azijski socijalistički pokret, čak su se i u SI počeli sve više ravnati prema stavovima ASK, naročito po pitanju borbe protiv kolonijalizma i za samoopredeljenje, dok su od snaženja uloge ove organizacije, uprkos svim njenim slabostima, sve više strahovali i lokalni komunisti. ${ }^{115}$ Međutim, ove partije su postepeno počele da gube inicijativu u korist vladajućih snaga u svojim

110 „Dobar početak u Rangunu“, Međunarodna politika, god. 4, br. 3, (1953), 4.

111 Vladimir Dedijer, „Jugoslovenski pogled na problem saradnje u međunarodnom radničkom pokretu,“Međunarodna politika, god. 4, br. 10, (1953), 7-8.

112 AJ, CK SKJ, 507/IX, 17/II-3, Zabeleška o poseti Bo Kin Maung Galea Beogradu, 2. mart 1953.

113 „Third Force“, Socialist Asia, vol. 1, no. 7, (1954).

${ }_{114}$ Report of the First Asian Socialist Conference, Rangoon 1953, 76.

${ }^{115}$ NARA, CREST, CIA-RDP78-00915R000500160003-6, Brief on the ASC, 1956. 
zemljama, uz izuzetak Burme i Cejlona gde su socijalističke partije još uvek bile na vlasti. Kada je druga ASK bila održana u Bombaju početkom novembra 1956, činilo se da je to bio dobar trenutak da se konačno redefinišu ideje i prioriteti i formulišu novi odgovori na složenu međunarodnu situaciju koja se ubrzano menjala, pošto je to bio istorijski trenutak dvojne Suecke i Mađarske krize. Štaviše, završna rezolucija koju je usvojio ovaj skup jasno je pozicionirala ASK kao organizaciju koja se borila protiv kolonijalizma, vojnih saveza i prisustva vojnih baza na teritoriji zemalja Azije i Afrike, što su potom bile koncepcije i Pokreta nesvrstanih. ${ }^{116}$ Međutim, neki od delegata nastojali su da se jasno osudi učešće Izraela u napadu na Egipat, dok je predsedavajući U Ba Šve činio sve da kritikuje akciju Britanije i Francuske, skrećući povremeno debatu i na osudu sovjetske intervencije u Mađarskoj, ali je otvoreno izbegavao da isto to učini i u slučaju Izraela, člana ove organizacije, što je izazvalo brojna negodovanja i sveopštu napetost. ${ }^{117}$ Diskusija se često više vodila o sovjetskom imperijalizmu u Istočnoj Evropi, koji se nije direktno doticao postkolonijalnog sveta, nego što se govorilo o otvorenoj agresiji na jednu afro-azijsku zemlju, čime je ASK sve više gubila svoj autoritet. ${ }^{118}$ Kao što je jedan učesnik primetio, ova organizacija je sve više postajala „mala azijska UN“, ,imajući samo snagu da pravi nacrte rezolucija“, dok su nove podele između njenih članova bivale sve očiglednije. ${ }^{119}$

Od sredine 1950-ih veze SKJ i ASK su sve više stagnirale usled neregulisanog rada Sekretarijata i unutrašnjih, pre svega finansijskih, problema koje je ova međunarodna organizacija imala, tako da se ranija bogata saradnja sve više svodila na povremeno objavljivanje članaka jugoslovenskih autora. Jugosloveni su sve više zamerali azijskim socijalistima na njihovom još uvek žestokom antikomunizmu, iako su se sovjetska i kineska politika postepeno počele menjati, ali i na sve manjoj sposobnosti da ispravno sagledaju realnu situaciju na tom kontinentu, preuzmu političku inicijativu i podrže neke od vladajućih elita. ${ }^{120}$ Tako je tokom druge ASK došlo do žestoke rasprave između Vladimira Bakarića i U Ba Švea oko pitanja izbegavanja osude izraelske agresije i namernog skretanja pažnje na Mađarsku, iako se ovde radilo o punopravnom članu ove organizacije koji je učestvovao u neprihvatljivim aktivnostima. ${ }^{121}$ Iako su jugoslovenske primedbe bile uvažene kroz blažu rezoluciju o Mađarskoj, Bakarić nije bio zadovoljan razvodnjenim formulacijama o izraelskim postupcima, tako da je jugoslovenska delegacija odlučila da napusti ovaj skup uz reči da Jugoslavija „u borbi protiv agresije ne pravi razliku između prijatelja i drugih nacija“, što je bila implicitna kritika bliskih burmansko-izraelskih veza. ${ }^{122}$ Isto tako, indonežanski delegat Sjahrir je uputio otvorenu kritiku Jugoslovenima da su pokušavali da dokažu kako se principi slobode mogu pomiriti sa totalitarnom praksom komunizma, u šta je

\footnotetext{
${ }^{116}$ S. Rose, Socialism in Southern Asia, 247-252.

${ }^{117}$ MHC, HRC, Statement by U Ba Swe on the present crisis in West Asia, 2. novembar 1956.

${ }^{118}$ MHC, HRC, Speech by U Ba Swe, Chairman of the ASC, 4. novembar 1956.

119 S. Rose, Socialism in Southern Asia, 254-255.

${ }^{120}$ AJ, CK SKJ, 507/IX, 144/I-42, Pismo Krste Bulajića Veljku Vlahoviću, 20. januar 1956.

${ }^{121}$ MHC, HRC, Speech by Vladimir Bakarić of Yugoslavia, 4. novembar 1956.

${ }^{122}$ AJ, CK SKJ, 507/IX, 144/I -43, Zasedanje ASK, 1956.
} 
on dosta sumnjao, iako je pohvalio jugoslovensku hrabrost da raskinu sa Moskvom. ${ }^{123}$ Situacija u međusobnim odnosima je postajala još napetija kada su neki indijski delegati na narednom sastanku Biroa ASK u Katmanduu marta 1958. hteli da diskutuju o slučaju Đilasovog izbacivanja iz partije, što je jugoslovenska strana uspela da spreči intervencijom burmanskih predstavnika pošto SKJ više nije učestvovao u radu ovog tela. Tadašnja odluka ASK da ne pošalje delegaciju na VII kongres SKJ ujedno je predstavljala kraj međusobnih odnosa, mada je i sama organizacija uskoro prestala da postoji usled sve manjeg značaja socijalističkih partija u političkom životu azijskog kontinenta. ${ }^{124}$

Ipak, političke snage koje su predvodili prepoznatljivi nacionalni lideri afro-azijskih zemalja (Nehru, Naser, Sukarno) postepeno su preuzimale primat i one su bile sve veći zagovornici nesvrstanosti i autoritarnog socijalističkog modela razvoja, dok su azijski socijalisti sve više ostajali na društvenoj margini, bez jasne strategije i svežih ideja, čekajući da ih iz bezdana izvuče SI, što je bio jasan pokazatelj koliko su već bili nisko pali. ${ }^{125}$ Uprkos svemu tome, u borbi za nacionalno oslobođenje, ekonomski razvoj i nezavisnu poziciju u svetskoj politici ASK je ne samo bila vesnik novih trendova koji su se pomaljali širom Azije i Afrike, već je razvijala sopstveni identitet naporedo sa sličnim težnjama drugih političkih snaga u azijskim društvima, što ju je činilo itekako istorijski relevantnom. Štaviše ASK se, usled svoje ideološke i političke distance od oba bloka, može lako posmatrati i kao jedan od ključnih kamenova na dugom putu nastanka Pokreta nesvrstanih zemalja, upravo zbog svoje univerzalističke i vanblokovske pozicije koju je zagovarala, što nije bio slučaj sa pretežno regionalnim i radikalnim bandunškim modelom. U oba ova slučaja Jugoslavija je svojim aktivnim delovanjem i principijelnim nastupom dala konkretan doprinos oblikovanju globalnog odgovora na ideološki i spoljnopolitički monopol koji su diktirala oba bloka.

\section{REFERENCE}

- Asian Relations: Report of the Proceedings and Documentation of the First Asian Relations Conference, New Delhi, March-April 1947. New Delhi: Asian Relations Organization, 1948.

- Bebler, Aleš. Putovanja po sunčanim zemljama. Beograd: Kultura, 1954.

- Bhargava, G. S. „Positive Aspects of Asian Socialism“. Pacific Affairs, vol. 26, no. 3 (1953), 236-244.

- Borba komunista Jugoslavije za socijalističku demokratiju: VI kongres KPJ (SKJ). Beograd: Kultura, 1952.

- Broz, Josip Tito. Govori i članci, VI. Zagreb: Naprijed, 1959.

- British Documents on Foreign Affairs: Reports and Papers from the Foreign Office Confidential Print 1948-1956, Part 5, Series E, Asia, 1953, vol. 5. University Publications of America, 2007.

${ }^{123}$ S. Rose, Socialism in Southern Asia, 257.

${ }^{124}$ AJ, CK SKJ, 507/IX, 17/II-18, Naši dosadašnji odnosi sa SPB i ASK, 1959.

${ }^{125}$ P. Van Kemseke, Towards an Era of Development, 146-147. 
- Čavoški, Jovan. "Arming Nonalignment: Yugoslavia's Relations with Burma and the Cold War in Asia, 1950-1955". CWIHP Working Paper, no. 61. Washington, DC: Woodrow Wilson Center, 2010.

- Dedijer, Vladimir. „Jugoslovenski pogled na problem saradnje u međunarodnom radničkom pokretu“. Međunarodna politika, god. 4, br. 10, (1953), 9-10.

- Dimić Ljubodrag, Aleksandar Raković, i Miladin Milošević. Jugoslavija - Indonezija 1945-1967: istraživanja i dokumenta. Beograd: Arhiv Jugoslavije, 2014.

- „Dobar početak u Rangunu“. Međunarodna politika, god. 4, br. 3, (1953), 4.

- Đilas, Milovan. Vlast i pobuna. Beograd: Književne novine, 1991.

- Imlay, Talbot C. "International Socialism and Decolonization during the 1950s: Competing Rights and the Postcolonial Order". American Historical Review, vol. 118, no. 4, (2013), 1105-1132.

- Kemseke, Peter Van. Towards an Era of Development: The Globalization of Socialism and Christian Democracy 1945-1965. Lueven: Lueven University Press, 2006.

- Kol. „Da li je moguća treća sila? “, Međunarodna politika, god. 5, br. 107, (1954), 7-8.

- Kyaw Zaw Win. A History of the Burma Socialist Party 1930-1964, PhD thesis. University of Wollongong, 2008.

- Kyaw Zaw Win. "The 1953 Asian Socialist Conference in Rangoon: precursor to the Bandung conference". Derek McDougall, Antonia Finnane (eds.), Bandung 1955: little histories. Caulfield: Monash University Press, 2010.

- Liang, Chi-shad. Burma's Foreign Relations: Neutralism in Theory and Practice. New York: Praeger, 1990.

- Miletić, Aleksandar. „Spoljnopolitička delatnost Milovana Đilasa 19441953“. Jugoslovenska diplomatija 1945-1961: zbornik radova. Urednik Slobodan Selinić, 291-312. Beograd: INIS, 2012.

- Nakanishi, Yoshihiro. Strong Soldiers, Failed Revolution: The State and Military in Burma, 1962-1988. Singapore, Kyoto: NUS Press, Kyoto University Press, 2013.

- Niclas-Tölle, Boris. The Socialist Opposition in Nehruvian India 1947-1964. Frankfurt am Main: Peter Lang Edition, 2015.

- „Pred konferenciju azijskih socijalista“. Međunarodna politika, god. 4, br. 1, (1953), 4-5.

- Report of the First Asian Socialist Conference, Rangoon 1953. Rangoon: An Asian Socialist Publication, 1953.

- Rose, Saul. Socialism in Southern Asia. New York: Octagon Books, 1975.

- Rubinstein, Alvin Z. Yugoslavia and the Nonaligned World. Princeton: Princeton University Press, 1970.

- „Socijalistička konferencija u Rangunu“. Međunarodna politika, god. 3, br. 9, (1952), 5-6.

- "Third Force". Socialist Asia, vol. 1, no. 7, (1954).

- Three Years of Asian Socialist Conference. Bombay: Second Congress ASC, 1956. 
- Trager, Frank N. “Burma's Foreign Policy, 1948-56: Neutralism, Third Force and Rice". The Journal of Asian Studies, vol. 16, no. 1, (1956), 89-102.

- U Ba Swe. The Burmese Revolution. Rangoon, 1952.

- U Kyaw Nyein. "Common Ties that Bind Us Together". Socialist Asia, vol. 1, no. 3, (1952), 1-2.

JOVAN ČAVOŠKI, PhD, Research Associate

Institute for Recent History of Serbia

Belgrade, Republic of Serbia

jcavoski@yahoo.com

\section{IDEOLOGICAL FRIEND FROM AFAR: YUGOSLAVIA AND THE ASIAN SOCIALIST CONFERENCE}

\section{Summary}

This article deals with an almost forgotten historical episode tackling the relationship between Yugoslavia and some influential Asian socialist parties that managed to establish an independent regional political organization in the early 1950s, namely the Asian Socialist Conference (ASC). During the Cold War many of the post-colonial nations sought to find a different path of socioeconomic development for their respective societies, aspiring in parallel for foreign policy independence and equality in world affairs, as well as trying to set up an alternative ideological and political framework to the existing bloc divisions. The ASC was one of the least understood events in the recent history of the Asian continent. This was an international organization that aspired to see the world from a quite different ideological perspective, a body established by the influential socialist parties of leading Asian non-aligned states, like Burma, India, and Indonesia. This double allegiance to socialism and non-alignment was the driving force behind the policies of this organization. At the same time, these parties were closely supported by Yugoslavia, the only communist renegade from the Soviet bloc who sought its own path of constructing a socialist society. Yugoslavia was the only non-Asian country that was fully accepted as an equal participant in this organization, thus truly making the ASC international in its scope and goals vis-à-vis both blocs and the wider world. Even though the ASC was not a very successful attempt, due to the later political weakness of all these socialist parties, since only few of them ever became ruling ones, it did, however, exercise an important role in shaping of an autonomous political identity of Asia and the non-aligned world during the 1950s. Yugoslavia's role in this respect was more than tangible.

KEYWORDS: Yugoslavia, Asian Socialist Conference, socialism, nonalignment, Third Force, Burma, India 